\title{
PENGARUH BERBAGAI DOSIS CITRININ TERHADAP KERUSAKAN STRUKTUR HEPATOSIT MENCIT (MUs musculus) PADA TIGA ZONA LOBULUS HEPAR
}

\section{THE EFFECT OF SEVERAL DOSES OF CITRININ TO THE HEPATOCYTE STRUCTURE DAMAGE OF MICE (Mus musculus) ON THREE HEPAR LOBULUS ZONE}

\author{
Utami Sri Hastuti \\ Jurusan Biologi - FMIPA Universitas Negeri Malang
}

\begin{abstract}
Citrinin is a sort of mycotoxin which caused mycotoxicosis. Citrinin is produced by Penicillium citrinum mold that can contaminate sort of food especially damaged beans. Citrinin is known as nephrotoxic as well as hepatotoxic mycotoxin and caused hepatocite structure damage. This research was done: 1) to know the effect of citrinin to hepatocite structure damage; 2) to know the effect of citrinin dose difference to the value of the hepatocyte structure damage; 3) to know the effect of citrinin to the value of hepatocyte structure damage on three zones of hepar lobulus. The samples of this research were male mice (Mus musculus) var. BALB-C at the age of three months. The experiment group of mice was orally administered with citrinin in three doses, i.e: dose-1: $1 \mathrm{mg} / \mathrm{kg} \mathrm{BW;} \mathrm{dose-2:} \mathrm{1,75} \mathrm{mg/kg} \mathrm{BW;} \mathrm{dose-3:} \mathrm{2,5} \mathrm{mg/kg} \mathrm{BW.}$ Hepatocyte structure damage is observed on centrilobular zone, midzone, and perifer zone. The hepatocyte structure damage examination is done by histopathologycal and ultra structural examination by electron microscope. The research results showed that: 1) there was an effect of citrinin to hepatocyte structure damaged cellular as well as sub cellular; 2) there was a difference effect of some dose of citrinin on the value of hepatocyte structure damaged by cellular; 3) dose-3 $(2,5 \mathrm{mg} / \mathrm{kg} \mathrm{BW})$ was the highest dose which cause hepatocyte damage on three zones of hepar lobulus; 4) citrinin effect was different for on hepatocyte, on three zones of hepar lobulus; 5) the perifer zone was the highest damaged area of three hepar lobulus zones.
\end{abstract}

Key words: citrinin dose, hepatocyte structure damage, hepar lobulus zone

\section{PENDAHULUAN}

Citrinin merupakan salah satu jenis mikotoksin yang dihasilkan oleh kapang Penicillium citrinum. Spesies kapang tersebut dapat mengkontaminasi berbagai macam bahan makanan terutama biji-bijian yang telah mengalami kerusakan dengan ciri-ciri antara lain: biji berlubang, keriput, mengelupas sehingga mudah terkontaminasi oleh sporaspora kapang, bila dibandingkan dengan biji-bijian utuh. Citrinin dapat terkandung dalam bahan makanan berupa beras, jagung, gandum, dan tomat busuk (1).

Jenis mikotoksin yang paling banyak dikenal dan mendapat perhatian khusus dari pakar dalam bidang kesehatan dan kedokteran di Indonesia adalah: aflatoksin, walaupun masih banyak jenis-jenis mikotoksin lain yang juga dapat mengganggu kesehatan (2). Citrinin dikenal sebagai mikotoksin yang bersifat nefrotoksik $(3,4)$. Citrinin bersifat nefrotoksik terhadap tikus dan babi yang ditandai dengan pembengkakan ginjal, perubahan degeneratif pada tubulus proksimal, nukleus mengalami piknosis dan dilatasi pada tubulus-tubulus (3).

Jurnal Kedokteran Brawijaya, Vol. XXII, No. 3, Desember 2006 Korespondensi: Utami Sri Hastuti; Jurusan Biologi -FMIPA Universitas Negeri Malang; Jl. Veteran Malang
Mikotoksin yang terpapar ke dalam tubuh bersamasama makanan dan tersebar melalui sistem peredaran darah akan berpengaruh pada organ-organ yang dilalui. Berdasarkan hal tersebut, maka ada kemungkinan bahwa citrinin selain bersifat nefrotoksik juga bersifat hepatotoksik. Target organ dari citrinin ialah ginjal, yang ditunjukkan dengan perubahan-perubahan patologik pada tubulustubulus ginjal pada kebanyakan hewan percobaan termasuk mencit, tikus, kelinci dan babi (5). Mikotoksin yang bersifat hepatotoksik dapat menyebabkan kerusakan struktur hepatosit. Kerusakan struktur hepatosit dapat terjadi pada hepatosit-hepatosit yang terdapat pada ketiga zona lobulus hepar, yaitu: zone perifer, zone midzonal dan zone centrilobular. Sampai saat ini belum ada informasi mengenai pengaruh citrinin terhadap kerusakan struktur hepatosit pada tahap-tahap degenerasi keruh, degenarasi hidropik, degenerasi lemak, dan nekrosis.

Hepar merupakan organ utama yang berperan penting dalam proses metabolisme berbagai macam senyawa, termasuk mikotoksin yang terpapar ke dalam tubuh. Di dalam hepar terjadi biotransformasi terhadap mikotoksin-mikotoksin yang masuk ke dalam tubuh bersama makanan. Dalam proses biotransformasi tersebut, mikotoksin dapat mengalami bioaktivasi menjadi senyawa lain yang bersifat lebih toksik bila dibandingkan dengan 
senyawa asli. Hal ini mengakibatkan fungsi detoksifikasi menurun, sehingga mikotoksin tersebut berikatan dengan mikromolekul-mikromolekul lain dalam sel. Sel-sel yang menyusun jaringan hepar dapat mengalami jejas seluler. Salah satu faktor penyebab jejas seluler ialah mikotoksin, yang merupakan senyawa kimia hasil metabolisme sekunder yang bersifat toksik, yang dihasilkan oleh kapang.

Sehubungan dengan hal tersebut, maka perlu dilakukan penelitian tentang pengaruh citrinin yang telah diketahui bersifat nefrotoksik dan hepatotoksik pada sel-sel hepatosit baik pada tingkat seluler maupun subseluler.

Penelitian ini bertujuan untuk: 1) mengetahui pengaruh pemberian citrinin terhadap kerusakan struktur hepatosit baik secara seluler maupun sub seluler; 2) mengetahui pengaruh perbedaan dosis citrinin terhadap tingkat kerusakan struktur hepatosit; 3) mengetahui pengaruh pemberian citrinin terhadap tingkat kerusakan struktur hepatosit pada tiga zona lobulus hepar

\section{METODE}

Penelitian ini merupakan penelitian eksperimen dengan rancangan acak kelompok. Penelitian ini dilakukan untuk mengetahui pengaruh paparan citrinin dengan beberapa macam dosis yang berbeda terhadap tingkat kerusakan struktur hepatosit pada ketiga zona lobulus hepar mencit yaitu zona perifer, midzone dan zone centrilobular. Penelitian ini dilakukan di laboratorium Farmasi UNAIR, Laboratorium Patologi FK UNAIR, Laboratorium Mikroskopi Elektron UNAIR dan Laboratorium Medis Klinika Surabaya.

Sampel dalam penelitian ini adalah mencit (Mus musculus) varietas BALB-C jantan berumur 3 bulan dengan berat badan antara $25-30$ gram.

Alat-alat yang digunakan dalam penelitian ini terdiri dari: kotak untuk mencit, timbangan, siring,masker, sarung tangan, pinset, pisau, alat bedah, papan bedah, mikrotom, autotechnicon, ultra microtom, inkubator, mikroskop cahaya, mikroskop elektron.

Bahan-bahan yang digunakan dalam penelitian ini adalah: metanol, standart mikotoksin dari SIGMA: citrinin standart, larutan buffer. Formalin 10\%, parafin, alkohol, xylol, hematoxylin, eosin, canada balsam, mencit umur 3 bulan dengan berat badan rata-rata 25-30 gram.

Prosedur penelitian, terdiri dari beberapa tahap penelitian yaitu 1). persiapan untuk hewan percobaan: dengan menyediakan kotak pemeliharaan mencit yang memiliki daya tampung masing-masing kotak pemeliharaan berisi 6 ekor mencit. Masing-masing perlakuan dosis menggunakan 6 ulangan ditambah perlakuan kontrol. 2). penentuan dosis mikotoksin, yaitu: dosis I $=1 \mathrm{mg} / \mathrm{kg} \mathrm{BB}$; dosis II = 1,75 mg/kg BB; dosis III yaitu = 2,5 mg/kg BB. 3). perlakuan pada hewan percobaan: setelah mengalami masa adaptasi, mencit yang termasuk kelompok eksperimen mendapat perlakuan paparan citrinin peroral tiap hari selama 4 hari, tiap paparan terdiri dari 3 macam dosis sedangkan perlakuan diberi larutan yang merupakan pelarut citrinin (selutio petit). Setelah pemaparan selama 4 hari dilakukan pembedahan mencit dan diambil heparnya untuk pemeriksaan histopatologik terhadap kerusakan struktur hepatosit dengan pemeriksaan mikroskopis terhadap sediaan jaringan hepar, serta untuk pemeriksaan ultra struktur dengan mikroskop elektron jenis Transmission Electron Microspe (TEM). 4). pembuatan preparat untuk pemeriksaan histopatologik: dilakukan dengan pembuatan blok jaringan hepar dalam parafin, kemudian dilakukan pemotongan blok parafin dengan ukuran tebal 3 mikron, lalu dibuat sediaan yang diwarnai dengan zat pewarna hematoxylin eosin, selanjutnya dilakukan pengamatan dengan mikroskop cahaya. 5). pembuatan preparat untuk pemeriksaan dengan mikroskop elektron: hepar mencit dipotong dengan ukuran $1 \times 1 \times 1 \mathrm{~cm}^{3}$, kemudian dicuci dengan buffer pospat dengan $\mathrm{pH} 7,4$ yang diulang 3 kali. Potongan jaringan tersebut kemudian dimasukkan dalam larutan glutaraldehid $2 \%$ dan dibiarkan selama 3 jam, kemudian dipindah kedalam larutan buffer pospat $\mathrm{pH} 3$ dan disimpan pada suhu $4^{\circ} \mathrm{C}$. Kemudian dilakukan dehidrasi dan pembuatan blok jaringan hepar dalam epon. Setelah itu dilakukan pemotongan blok epon dengan ultra microtom dan sediaan diwarnai dengan Toluidine Blue. Setelah itu dilakukan pemotongan blok epon dengan ketebalan 60-90 $\mathrm{nm}$. Lalu irisan diletakkan di atas grid. Kemudian sediaan diwarnai dengan uranyl acetat. Sisa uranil acetat dicuci dengan aquades dan kemudiaan dikeringkan, selanjutnya diamati dengan mikroskop elektron. 6). pemeriksaan kerusakan struktur hepatosit secara mikroskopis: dilakukan pada medan pandang antara vena centralis dan segitiga kiernan yang terdiri dari 3 zona yaitu: zone centrilobular, zone midzonal dan zone perifer, kemudian dilakukan pemeriksaan dan penghitungan jumlah hepatosit yang mengalami beberapa tingkat kerusakan dengan ketentuan sebagai berikut: kerusakan I (degenerasi keruh), kerusakan II (degenerasi hidropik), kerusakan III (degenerasi lemak) dan kerusakan IV (nekrosis) dari tiap 100 hepatosit yang terdapat dalam tiap-tiap sub medan pandang mikroskop. Penghitungan hepatosit dilakukan dengan bantuan mikrometer berkisi. Pengamatan kerusakan struktur hepatosit pada tingkat subseluler dilakukan dengan mikroskop elektron jenis Transmission Electron Microscope (TEM). 7). analisis data dilakukan menggunakan Analisis Variansi Ganda (ANAVA) yang dilanjutkan dengan uji lanjut BNJ 1\% terhadap data yang diperoleh yang berupa nilai tingkat kerusakan struktur hepatosit mencit akibat pengaruh paparan citrinin. 
Tabel 1. Ringkasan Sidik Ragam Pengaruh Paparan Citrinin terhadap Kerusakan Struktur Hepatosit Mencit

\begin{tabular}{lllllc}
\hline \multicolumn{1}{c}{ SK } & $\mathrm{db}$ & $\mathrm{JK}$ & $\mathrm{KT}$ & $\mathrm{F} \mathrm{hit}$ & $\mathrm{F}$ tab 1\% \\
\hline Ulangan & 5 & 4,078 & 8,6 & 3,166 & 0,014 \\
Dosis & 3 & 9768,973 & 3256,324 & 12638,948 & 0,000 \\
Zona & 2 & 814,021 & 407,011 & 1579,752 & 0,000 \\
Dosis-Zona & 6 & 343,167 & 57,195 & 221,992 & 0,000 \\
Galat & 55 & 14,170 & 258 & & \\
Total & 72 & 3373,101 & & & \\
\hline Ket & & & & &
\end{tabular}

Keterangan:

SK: Sumber keragaman; Db: Derajat bebas; JK: Jumlah Kuadrat; KT: Kuadrat Tengah; F hit: F hitungan; F tab: F tabel

\section{HASIL PENELITIAN}

Data hasil penelitian mengenai pengaruh paparan citrinin dengan beberapa macam dosis terhadap kerusakan struktur hepatosit mencit pada 3 zona lobulus hepar seperti nampak pada Ringkasan Sidik Ragam pada Tabel 1.

Berdasarkan Hasil analisis data dapat diketahui bahwa ada pengaruh beberapa macam dosis paparan citrinin terhadap kerusakan struktur hepatosit mencit, dan ada pengaruh paparan citrinin terhadap kerusakan struktur hepatosit pada ketiga zone lobulus hepar serta ada pengaruh interaksi dosis paparan citrinin dan zone lobulus hepar terhadap tingkat kerusakan srtuktur hepatosit mencit, hal ini dapat dilihat pada $\mathrm{F}$ hit $>\mathrm{F}$ tab $0,1 \%$ yang menunjukkan adanya pengaruh yang signifikans pada taraf $0,1 \%$.

Selanjutnya untuk mengetahui perbedaan pengaruh macam dosis paparan citrinin terhadap kerusakan struktur hepatosit mencit dan perbedaan pengaruh paparan citrinin terhadap kerusakan struktur hepatosit pada ketiga zona lobulus hepar, maka dilakukan uji lanjut BNJ 1\% seperti nampak pada Tabel 2.

Tabel 2 Uji BNJ 1\% Pengaruh Dosis Paparan citrinin

\begin{tabular}{cccc}
\hline Dosis & Rerata & & Notasi \\
\hline 0 & 0,000 & a & \\
I & 198,944 & \multicolumn{2}{c}{ b } \\
II & 697,056 & \multicolumn{2}{c}{ c } \\
III & 976,278 & \multicolumn{2}{c}{ d } \\
\hline
\end{tabular}

Keterangan:

Dosis 0 : Kontrol

Dosis I : $1 \mathrm{mg} / \mathrm{kg} \mathrm{BB}$

Dosis II : $1,75 \mathrm{mg} / \mathrm{kg} \mathrm{BB}$

Dosis III : $2,5 \mathrm{mg} / \mathrm{kg} \mathrm{BB}$

Notasi menunjukkan perbedaan efek

Hasil uji BNJ 1\% membuktikan bahwa dosis III (2,5 $\mathrm{mg} / \mathrm{kg} \mathrm{BB}$ ) paparan citrinin memberikan pengaruh tertinggi terhadap tingkat kerusakan struktur hepatosit. Kerusakan struktur hepatosit makin meningkat seiring dengan peningkatan dosis. Pemeriksaan mikroskopis terhadap tingkat kerusakan struktur hepatosit mencit menunjukkan bahwa makin tinggi dosis paparan citrinin makin banyak hepatosist yang mengalami nekrosis. Deskripsi hasil pemeriksaan mikroskopis hepatosit normal dan hepatosit yang mengalami nekrosis dapat dilihat pada Gambar 1 dan 2.

Tabel 3. Uji BNJ 1\% Pengaruh Paparan Citrinin pada Zona Lobulus Hepar

\begin{tabular}{ccc}
\hline Zona Lobulus Hepar & Rerata & Notasi \\
\hline 1 & 266,000 & a \\
2 & 462,92 & b \\
3 & 675,29 & c \\
\hline
\end{tabular}

Keterangan:

Zona 1: Zone Centrilobular

Zona 2: Zone Midzonal

Zona 3: Zona perifer

Notasi menunjukkan perbedaan efek

Hasil Uji BNJ 1\% Pengaruh paparan citrinin pada zona lobulus hepar membuktikan bahwa kerusakan struktur hepatosit tertinggi akibat paparan citrinin terjadi pada zona perifer.

Hasil pemeriksaan kerusakan struktur sub seluler pada hepatosit menggunakan mikroskop elektron menunjukkan bahwa kerusakan struktur hepatosit meningkat seiring dengan peningkatan dosis paparan citrinin. Dosis I (1 mg/kg BB) menyebabkan mitokondria mulai membengkak, sedangkan membran nukleus dan retikulum endoplasmik masih dalam keadaan normal (Gambar 1). Deskripsi pengamatan sub seluler mikroskopis sel hepatosit normal dan pengaruh paparan citrinin pada dosis I nampak seperti Gambar 4 dan 5.

Pengaruh paparan citrinin dosis II (1,75 mg/kg BB) menyebabkan mitokondria makin membengkak dan krirta mitokondria nampak kabur, sedangkan membran nukleus dan retikulum endoplasmik mulai rusak ( Gambar 6). Dosis III $(2,5 \mathrm{mg} / \mathrm{kg} \quad \mathrm{BB})$ paparan citrinin menyebabkan mitokondria sangat membengkak dan mulai pecah, retikulum endoplasmik rusak dan terputus-putus, membran nukleus robek pada beberapa tempat, sitoplasma nampak berongga-rongga yang kemungkinan berasal dari organelaorganela yang telah pecah dan lisis. (Gambar 7). Deskripsi pengamatan mikroskopis sub seluler sel hepatosit dengan pengaruh paparan citrinin dengan dosis II dan dosis III nampak seperti Gambar 6 dan 7. 


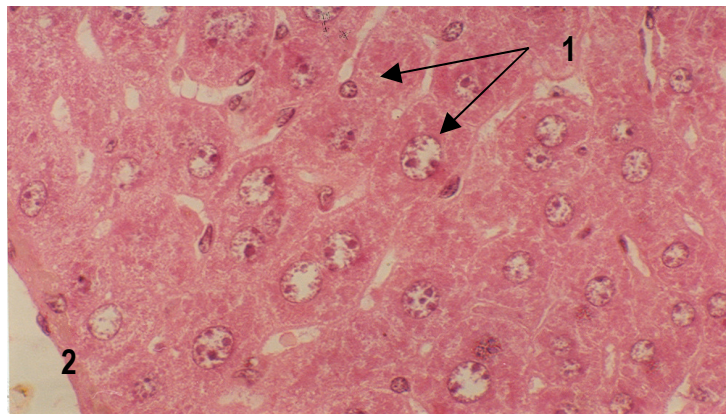

Gambar 1.Foto Mikroskopis Hepatosit Normal (perbesaran 1000X)

Keterangan:

1) hepatosit, 2) vena centralis

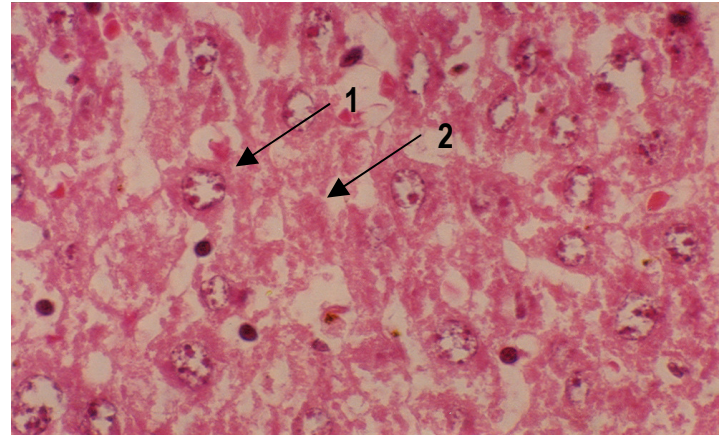

Gambar 2. Foto Mikroskopis Hepatosit yang Mengalami Nekrosis (perbesaran 1000X)

Keterangan:

1) karioreksis, 2) kariolisis

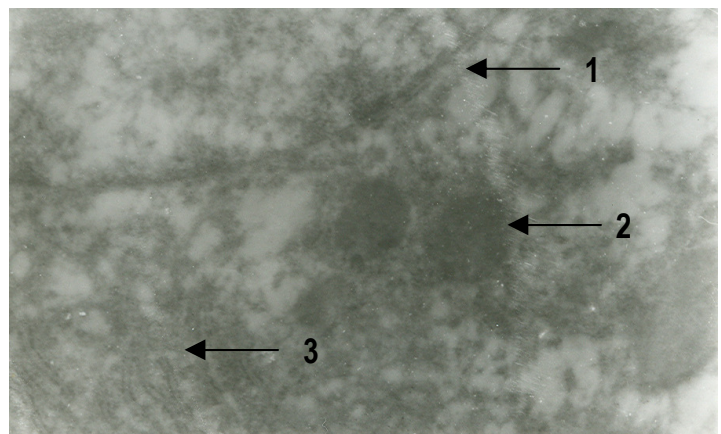

Gambar 4.Foto Mikroskopis Sel Hepatosit Normal (perbesaran 1500X)

Keterangan:

1) membran inti, 2) mitokondria, 3) Endoplasmic Reticulum (ER)

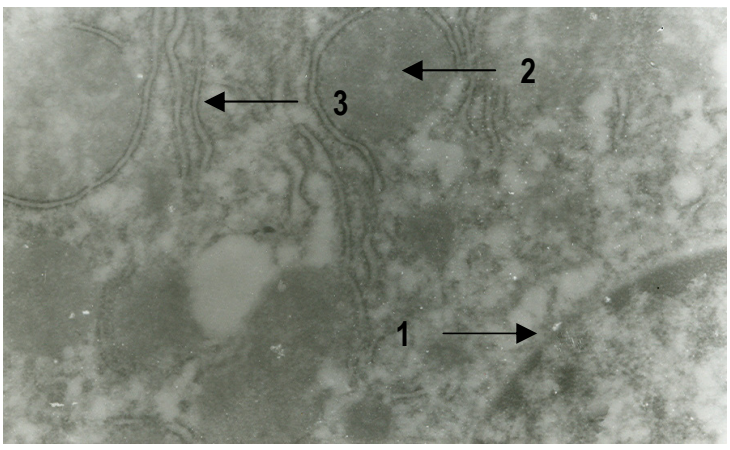

Gambar 5.Foto Mikroskopis Sel Hepatosit pada Paparan Citrinin Dosis I (perbesaran 1500X)

Keterangan:

1) membran inti normal, 2) mitokondria mulai membengkak,

3) Endoplasmic Reticulum (ER) normal

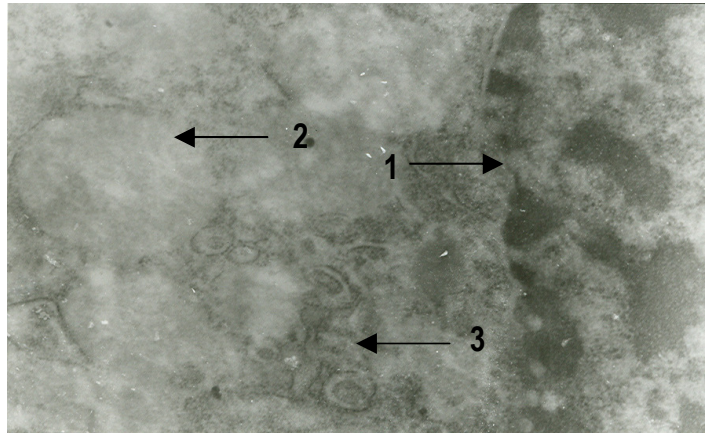

Gambar 6.Foto Mikroskopis Sel Hepatosit pada Paparan Citrinin Dosis II (perbesaran 1500X)

Keterangan:

1) membran inti rusak, 2) mitokondria membengkak,

3) Endoplasmic Reticulum (ER) mulai rusak

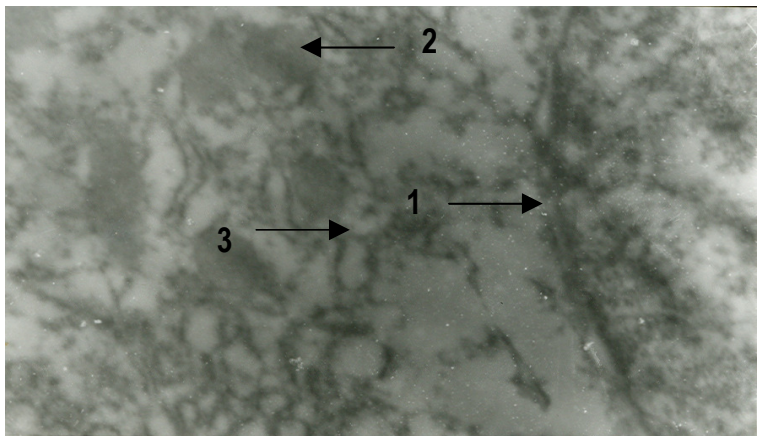

Gambar 7.Foto Mikroskopis Sel Hepatosit pada Paparan Citrinin Dosis III (perbesaran 1500X)

Keterangan:

1) membran initi rusak, 2) mitokondria mulai pecah,

3) Endoplasmic Reticulum (ER) rusak 


\section{DISKUSI}

Hasil pemeriksaan histopatologik menunjukkan bahwa pemberian citrinin pada mencit peroral menyebabkan kerusakan struktur hepatosit. Kerusakan struktur heaptosit ditandai dengan adanya perubahan degeneratif yang terdiri dari: degenerasi keruh, degenerasi hidropik, degenerasi lemak dan nekrosis. Degenerasi keruh merupakan tingkat kerusakan struktur hepatosit yang paling ringan dan tingkat kerusakan struktur ke-1 yang ditandai dengan ciri-ciri antara lain: hepatosit membengkak, sitoplasma bergranula, dan nampak tidak homogen. Hal ini disebabkan karena terjadi pemasukan air ke dalam hepatosit, sehingga sel membengkak. Organelaorganela sel juga turut menyerap air dan membengkak, sehingga mengakibatkan sitoplasma nampak bergranula.

Degenerasi hidropik merupakan tingkat kerusakan struktur ke-2 yang ditandai dengan ciri-ciri antara lain: sitoplasma mengalami vakuolisasi, vakuola-vakuola nampak jernih dan terjadi karena peningkatan pemasukan air ke dalam sel dan kemudian air memasuki vakuola-vakuola tersebut.

Degenerasi lemak merupakan tingkat kerusakan struktur ke-3, yang ditandai dengan ciri-ciri antara lain: di dalam sitoplasma hepatosit terbentuk satu vakuola besar yang berisi lemak, sehingga nukleus terdesak ke tepi sel. Lemak dalam bentuk trigliserida tidak dapat dikeluarkan dari dalam hepatosit dan tertimbun dalam vakuola yang terdapat di tengah hepatosit. Nekrosis merupakan tingkat kerusakan struktur ke-4, yang ditandai dengan ciri-ciri antara lain: nukleus mengkerut (piknosis), nukleus pecah menjadi fragmen-fragmen (kariokinesis), nukleus lisis (kariolisis), membran sel mengalami lisis sehingga batas antar sel tidak nampak jelas.

Hasil analisis data menunjukkan bahwa ada perbedaan nyata pengaruh dosis paparan citrinin terhadap tingkat kerusakan struktur hepatosit. Makin tinggi dosis citrinin, makin meningkat kerusakan struktur hepatosit. Hasil pemeriksaan kerusakan struktur sub seluler hepatosit menunjukkan bahwa kerusakan struktur hepatosit meningkat sesuai dengan peningkatan dosis citrinin. Dosis $I I(2,5 \mathrm{mg} / \mathrm{kg} \mathrm{BB})$ menyebabkan terjadinya kerusakan struktur hepatosit yang paling parah karena sebagian besar sel hepatosist telah mengalami nekrosis yang ditandai mitokondria sangat membengkak dan mulai pecah, membran nukleus robek pada beberapa tempat, sitoplasma nampak berongga-rongga dan retikulum endoplasmik rusak dan putus-putus.

Apabila citrinin masuk ke dalam saluran pencernaan bersama-sama makanan yang telah terkontaminasi oleh mikotoksin tersebut, maka citrinin dapat masuk ke dalam hepar bersama-sama darah melalui vena porta hepatica. Vena porta hepatica membentuk cabang-cabang nenuju lobus-lobus hepar, yaitu vena interlobularis. Cabang-cabang tersebut membentuk cabang lagi, yaitu vena interlobularis yang terdapat di daerah segitiga kiernan. Selanjutnya darah yang mengandung citrinin tersebut didistribusikan ke dalam sinuso- id-sinusoid yang berbatasan dengan hepatosit-hepatosit. Citrinin akan terpapar ke dalam hepatosit-hepatosit. Oleh karena zona perifer terletak paling dekat dengan vena inter-lobularis, maka hepatosit-hepatosit yang terletak pada zona perifer akan terpapar oleh citrinin lebih dahulu, kemudian diikuti dengan midzonal dan zona centrilobular. Hasil penelitian ini membuktikan bahwa kerusakan struktur hepatosit yang tertinggi terjadi pada hepatosit-hepatosit yang terdapat pada zona perifer.

Citrinin dapat menghambat beberapa jenis enzim respirasi bila terpapar ke dalam sel (6). Citrinin dapat menghambat aktivitas enzim malat dehidrogenase, yang merupakan biokatalisator dalam proses pembentukan asam oksaloasetat dari asam malat. Selain itu juga dapat menghambat aktivitas enzim 2-oxoglutarate, yang merupakan biokatalisator dalam pembentukan suksinil co A. Peristiwa tersebut berlangsung dalam siklus asam sitrat. Hal ini dapat menghambat pembentukan ATP. Di samping itu citrinin juga dapat menghambat aktivitas enzim ATP ase sehingga menurunkan jumlah ATP yang dihasilkan dalam siklus asam sitrat (4). Penurunan ATP dapat menghambat sistem pompa Natrium yang mengatur keluar masuknya ion-ion Natrium dan Kalium ke dalam sel, sehingga mengakibatkan ion $\mathrm{Na}$ banyak tertimbun dalam sitoplasma. Hal ini menyebabkan meningkatnya nilai osmosis dalam sitoplasma, sehingga terjadi pemasukan air dari ruang antar sel. Selanjutnya terjadi penggembungan sel dan organela-organela sel termasuk mitokondria dan dapat menyebabkan pecahnya hepatosit yang disebut nekrosis.

Hambatan aktivitas enzim-enzim respirasi akibat paparan citrinin mengakibatkan terhambatnya metabolisme dalam sel hepatosit sehingga terjadi penurunan ATP yang mengakibatkan kerusakan struktur hepatosit. Kerusakan pada mitokondria juga mengakibatkan hambatan pada respirasi seluler, karena enzim-enzim keluar dari mitokondria yang rusak tersebut, sehingga terjadi kematian hepatosit.

\section{KESIMPULAN}

Berdasarkan hasil analisis data dan diskusi maka dapat disimpulkan bahwa terdapat pengaruh pemberian citrinin terhadap kerusakan struktur hepatosit baik secara seluler dan sub seluler, pengaruh perbedaan macam dosis citrinin terhadap kerusakan struktur hepatosit, dosis III $(2,5$ $\mathrm{mg} / \mathrm{kg} \mathrm{BB}$ ) merupakan dosis yang paling tinggi menyebabkan kerusakan hepatosit baik secara seluler maupun sub seluler, terdapat perbedaan pengaruh pemberian citrinin terhadap tingkat kerusakan struktur hepatosit pada tiga zona lobulus hepar, dan zona perifer merupakan zona lobulus hepar yang paling parah tingkat kerusakaannya.

\section{SARAN}

Perlu dilakukan penelitian lanjut tentang frekuensi pemberian citrinin dengan variasi dosis citrinin terhadap tingkat kerusakan struktur hepatosit. 


\section{DAFTAR KEPUSTAKAAN}

1. Betina Vladimir. Mycotoxins-Chemichal, Biologycal and Enviromental Aspect, Isevier. Science Pulising Company, Inc; 1989; 174-265

2. Braunberg RC, et al. In Vitro Effects of The Nephrotoxin Ochratoxin A and Citrinin Upon Biochemical Function of Procine kidney. Arch.Environt. Contam.1992; 22:464-470

3. Budiarso, Iwan T. Toksin Jamur: dampaknya terhadap kesehatan Manusia. Makalah disajikan pada KONAS III PAMKI. Jakarta:3-5 Juli 1995

4. Chagas GM, Annibal P, Campello, and Ma. Lucia W. Kluppel. Mechanism of Citrinin Induced Dysfunction of Mitokondria I. effect on Respiration,Enzyme Activities and Membrane Potential of Renal Cortical Mitocondria. Journal of Applied Tocxicology 1992; 12(2): 123-129.

6. Chagas GM, Annibal P, Campello, and Ma. Lucia W. Kluppel. 1995. Mechanism of Citrinin Induced Dysfunction of Mitokondria II. effect on Respiration, Enzyme Activities and Membrane Potential of Liver Mitocondria. Cell Biochem. Func. 1995; 10: 209-216

7. Chagas GM, Annibal P, Campello, and Ma. Lucia W. Kluppel. 1992. Mechanism of Citrinin Induced Dysfunction of Mitokondrial. effect on Respiration, Enzyme Activities and Membrane Potential of Renal Cortical and Liver Mitocondria. Journal of Applied Tocxicology1992; 15 (2):91-95

8. Hastuti SU. Mikoflora Pada Biji lada Utuh dan biji lada Rusak di Kodya Malang. Makalah disajikan pada PIT dan Seminar Nasional Mikrobiologi Perhimbunan Mikrobiologi Indonesia (PERMI), Malang: PERMI cabang Malang, 12-13 November 1996.

9. Hayes. A Wallace. Mycotoxin Teratogenicity and Mutagenicity. Boca.Rotan. Florida: CRC Press, Inc; 1981.

10. Makfoeld, Djarir. Mikotoksin Pangan. Yogyakarta: kanisius; 1993. 